\title{
Homeopathy and Placebo - Synonym, Similar or Different?
}

\author{
Frank Zimmermann-Viehoffa Karin Meissner $^{\mathrm{b}}$ \\ a Psychosomatik, Charité, Campus Benjamin Franklin, Berlin, \\ bInstitut für Medizinische Psychologie, Ludwig-Maximilians-Universität München, Deutschland
}

Despite some evidence for the effectiveness of homeopathy from large-scale observational studies [1-4], the question whether its clinical effects are completely due to placebo remains subject of scientific debate $[5,6]$. The scepticism towards homoeopathy mainly results from the lack of a generally accepted scientific rationale of its action [7]. If everything that exists beyond a clearly defined physiological mechanism, e.g. drug-receptor interaction, is considered to be a placebo, then, at present, this is true for homeopathy.

In contrast, Samuel Hahnemann, the founder of homeopathy, spoke of the vital force or 'dynamis' as target of action of homeopathic remedies [8]. Modern homeopaths might argue that the remedy transports some kind of 'information' [9] that is able to stimulate the 'healing capacities' of the organism [10]. As we will point out, these explanation models are pretty much in line with modern placebo theories.

Placebos are used as controls in pharmacological studies and therefore can be seen as the most extensively investigated medicines worldwide. There is consensus that placebo phenomena exist, and that they are able to produce remarkable effects in medicine. Although effect sizes have been questioned [11], there are still consistent results that treatment with placebos can produce beneficial effects across various medical fields such as pain [11], neurology [12], cardiology [13, 14], and surgery [15]. And these effects are by no means only psychological, subjective phenomena, but accompanied by measurable changes in endocrine $[12,16]$ and autonomic functions [17]. In addition, placebos often mimic the central effects of the active drug $[12,18]$.

As complex interventions, many therapies of complementary and alternative medicine (CAM) have strong unspecific effects. In randomised controlled trials, it is therefore often difficult to prove superiority to placebo - a phenomenon that has been called the 'efficacy paradox' [19]. This point is underlined by the fact that CAM therapies are mostly assumed (and expected) to have a smooth, gentle action with minimal side effects.
In the case of homeopathy, placebo effects hardly can be attributed to some characteristics of the drug itself known to enhance placebo answers (e.g., colour of drug [20], invasiveness of application modus [21], degree of active involvement of the patient [22]). Typically, homeopathic remedies are taken as globuli, small sucrose-based pills, in larger time intervals. However, instructions like '5 globuli three times a day' might very well produce strong unspecific effects.

But classical homeopathy is more a holistic package of care, also comprising a special context of the homeopathic encounter. Recent placebo literature has emphasised the therapeutic relevance of factors like altruism, empathy, emotional care and subjective meaning of a treatment [23-26]. Specific features of homeopathy such as duration and method of case taking, or other characteristics of the doctor-patient relationship might therefore have a strong influence on health outcomes. 200 years ago, Hahnemann taught homeopaths to be unprejudiced observers, to listen to the patient without interrupting, remove obstacles of healing and to give advice regarding lifestyle changes [9]. Today, these principles are anchored in modern psychosomatic medicine.

With a few exceptions [27, 28], there is little systematic knowledge nowadays about homeopathic doctors' attitudes, their personal beliefs or communication skills, nor about their patients' expectations, suggestibility, or individual meaning of homeopathy as their therapy of choice.

There is little doubt that homeopathy, at least for a reasonable number of patients, can be beneficial. Whether its effects are produced by a specific action of the homeopathic remedy still has to be subject of basic and clinical research. For a more differentiated understanding which factors contribute to healing in homeopathy, observational research outside randomised controlled trials should look further for characteristics of the doctor-patient relationship in the context of homoeopathy.

\begin{tabular}{ll}
\hline KARGER & $\odot$ 2007 S. Karger GmbH, Freiburg \\
Fax +497614520714 & Accessible online at: \\
$\begin{array}{l}\text { E-mail Information@Karger.de } \\
\text { www.karger.com }\end{array}$ & www.karger.com/fok
\end{tabular}

Dr. Frank Zimmermann-Viehoff

Abt. für Psychosomatik und Psychotherapie

Charité Universitätsmedizin Berlin - Campus Benjamin Franklin

Hindenburgdamm 30, 12200 Berlin, Deutschland

Tel. +493084454046

E-mail frank.zimmermann@charite.de 


\section{References}

1 Witt CM, Lüdtke R, Baur R, Willich SN: Homeopathic medical practice: Long-term results of a cohort study with 3981 patients. BMC Public Health 2005;5:115.

2 Spence DS, Thompson EA, Barron SJ: Homeopathic treatment for chronic disease: a 6 year, university hospital outpatient observational study. J Altern Complement Med 2005;11(5):793-798.

$\checkmark 3$ Güthlin C, Lange O, Walach H: Measuring the effects of acupuncture and homoeopathy in general practice: An uncontrolled prospective documentation approach. BMC Public Health 2004;4:6.

$\checkmark 4$ Attena F, Del Giudice N, Verrengia G, Granito C: Homoeopathy in primary care: self-reported change in health status. Complement Ther Med 2000;8(1):21-25.

5 Linde K, Clausius N, Ramirez G, Melchart D, Eitel F, Hedges LV, Jonas WB: Are the clinical effects of homoeopathy placebo effects? A metaanalysis of placebo-controlled trials. Lancet 1997;350:834-843.

6 Shang A, Huwiler-Müntener K, Nartey L, Jüni P, Dörig S, Sterne JAC, Pewsner D, Egger M: Are the clinical effects of homoeopathy placebo effects? A comparative study of placebo-controlled trials of homoeopthy and allopathy. Lancet 2005;366:726732 .

7 Ernst E: Homoeopathy: the effective promotion of ineffective remedies? Br J Clin Pharmacol 2006; 62(6):645-646.

8 Hahnemann S: Organon der Heilkunst. Stuttgart, Haug, 1999.

9 Tiller WA: On chemical medicine, thermodynamics, and homeopathy. J Altern Complement Med 2006;12(7):685-693.

10 Bellavite P, Pitari G, Italiano M: Homeopathy and placebo. Homeopathy 2006;95(1):51.
Hróbjartsson A, Gøtzsche PC: Is the placebo powerless? An analysis of clinical trials comparing placebo with no treatment. N Engl J Med 2001;344: 1594-1602.

12 De la Fuente-Fernandez R, Stoessl AJ: The placebo effect in Parkinson's disease. Trend Neurosci 2001;25(6):302-306.

13 Bienenfeld L, Frishman W, Glasser SP: The placebo effect in cardiovascular disease. Am Heart J 1996;132(6):1207-1221.

14 Rana JS, Mannam A, Donnel-Fink L, Gervino EV, Sellke FW, Laham RJ: Longevity of the placebo effect in the therapeutic angiogenesis and laser myocardial revascularisation trials in patients with coronary heart disease. Am J Cardiol 2006;97(1): $152-153$.

15 Johnson AG: Surgery as a placebo. Lancet 1994; 344:1140-1142

16 Colloca L, Benedetti F: Placebos and painkillers: Is mind as real as matter? Nat Rev Neurosci 2005; 6(7):545-552.

17 Meissner K, Distel H, Mitzdorf U: Evidence for placebo effects on physical but not on biochemical outcome parameters. A review of clinical trials. BMC Med 2007;19(5):3.

18 Wager TD, Rilling JK, Smith EE, Sokolik A, Casey KL, Davidson RJ, Kosslyn SM, Rose RM, Cohen JD: Placebo-induced changes in fMRI in the anticipation and experience of pain. Science 2004; 303(5661):1162-1167.

19 Walach H: The efficacy paradox in randomized controlled trials of CAM and elsewhere: Beware of the placebo trap. J Altern Complement Med 2001; 7(3):213-218.
20 De Craen AJM, Roos PJ, de Vries AL, Kleijnen J: Effect of colour of drugs: systematic review of perceived effects of drugs and of their effectiveness. BMJ 1996;313:1624-1626.

21 Kaptchuk TJ, Stason WB, Davis RB, Legedza ATR, Schnyer RN, Kerr CE, Stone DA, Nam BH, Kirsch I, Goldman RH: Sham device vs. inert pill: randomised controlled trial of two placebo treatments. BMJ 2006;332(7538):391-397.

22 Saradeth T, Resch KL, Ernst E: Placebo for varicose veins - don't eat eat it, rub it! Phlebology 1994;9:63-66.

23 Mackenbach JP: On the survival of the altruistic trait in medicine: Is there a link with the placebo effect? J Clin Epidemiol 2005;58:433-435.

24 Di Blasi Z, Harkness E, Ernst E, Georgiou A, Kleijnen J: Influence of context effects on health outcome: a systematic review. Lancet 2001;357: 757-762.

25 Kaptchuk TJ: The placebo effect in alternative medicine: Can the performance of a healing ritual have clinical significance? Ann Intern Med 2002; 136:817-825.

26 Moerman DE, Jonas WB: Deconstructing the placebo effect and finding the meaning response. Ann Intern Med 2002;136:471-476.

27 Thompson TDB, Weiss M: Homoeopathy - what are the active ingredients? An exploratory study using the UK Medical Research Council's framework for the evaluations of complex interventions. BMC Complement Altern Med 2006;6:37.

28 Mercer SW: Practitioner empathy, patient enablement and health outcomes of patients attending the Glasgow Homoeopathic Hospital: a retrospective and prospective comparison. Wien Med Wochenschr 2006;155(21-22):498-501. 